\title{
Public Open Space's Contribution to Quality of Life: Does privatisation matters?
}

\author{
Achmad Delianur Nasution, Wahyuni Zahrah \\ Urban and Housing Laboratory, Architecture Department, \\ University of Sumatra Utara, Medan, Indonesia \\ wahyuni_zahrah@yahoo.com
}

\begin{abstract}
Quality of life of people in urban area is the outcome of people interaction with urban environment. Many studies indicate that public open space is one of important urban environment elements which give positive contribution to quality of life. This paper investigates how privatization of public open space affects quality of life of people while many studies show degradation of 'publicness' of public space due to privatization. Research ßnding indicates that people keep doing their social activities both in privatized and public area but physically segregated.
\end{abstract}

Keywords: urban open space privatization, social activity, quality of life

eISSN 2514-751X @ 2017 The Authors. Published for AMER ABRA by e-International Publishing House, Ltd., UK. This is an open-access article under the CC BY-NC-ND license (http://creativecommons.org/licenses/by-ncnd/4.0/). Peer-review under responsibility of AMER (Association of Malaysian Environment-Behaviour Researchers), ABRA (Association of Behavioural Researchers on Asians) and cE-Bs (Centre for EnvironmentBehaviour Studies), Faculty of Architecture, Planning \& Surveying, Universiti Teknologi MARA, Malaysia. 


\subsection{Introduction}

Research in quality of life is important as part of contribution to enhance quality of life itself (Lever, 2000). Quality of life of people in urban area is the outcome of people interaction with urban environment (Das, 2008). Many studies show that public open space (POS) is one important element of urban environment (Shirvani, 1985) which gives positive contribution to quality of life (Madanipour, 1999). In fact, public open space tends to decrease both in quality and quantity. One trigger of this condition is privatization, when public open space owned and or managed by private sector. Some studies see the privatization causes negative effects, such as limitation of access, increasing of consumerism, social gap, decreasing democracy expression and social interaction (Kruppa, 1993; Kressel, 1998; Day, 1999; Kohn, 2004). The others see positive effects of POS privatization, such as increasing of quality and management (Melik, 2009; Slangen, 2005) which in turn would increase quality of life (Beck, 2009). This paper will discuss how privatization of public open space affects quality of life, particularly in developing country such as Indonesia with lack of public open space, both in quality and quantity.

\subsection{Literature Review}

\section{Successful Public Open Space}

Public open space is outdoor spaces with free access for people (Jacobs, 1961; Madanipour, 1999), such as cafes, retail, bazaar, parks, streets and pedestrian paths. Public open space is success while it becomes conducive place for social interaction (Danisworo, 1989; Whyte, 1985), attracts many visitors to do their activities in there (Danisworo, 1989; Whyte, 1985), with wide range of activities occur (Rivlin, 1994; CABE and DETR, 2001), individual or group (Rossi, 1982; Gehl, 2002), informal and suitable for recreation (Whyte, 1985; Project for Public Space, 2000), democratic and non discriminative (Car, 1992), accessible for all class and age of people, including disable people and informal sector (Gehl, 2002;CABE and DETR, 2001).

Successful public open space should promote psychological comfort and safety (Danisworo, 1989). In physical dimension, the criteria of high quality public open space is the clear and easy access and movement system (Danisworo, 1989; Car, 1992; Rivlin, 1994; Project for Public Space, 2000; Gehl 2002; CABE and DETR, 2001). It could be attained by creating linkage as clear paths which connect each other (Project for Public Space, 2000; Gehl, 2002; CABE and DETR, 2001) and by integration of transportation mode and land use, the present of landmark as orientation (CABE and DETR, 2001), with human scale design (Asihara, 1981; Shirvani, 1985).

Pleasant public open space could be reach by high quality architecture, (Danisworo, 1989; Car, 1992), attractive building facade, (Gehl, 2002, CABE and DETR, 2001) and 
interesting scene and details (Gehl, 2002; Avila 2001). Natural elements are important factor in public open space that improve comfort, relaxation, pleasant experience and anticipate unpleasant climate by placing tress along pedestrian path and sitting area (Kaplan and Kaplan, 1989; Carr, 1992; Gehl, 2002; Avila, 2001).

\section{Public Open Space PrivatiSation}

Privatization is a kind of public-private partnership whereby private entities and city officials negotiate directly with one another (Slangen, 2005). There are some fields of public interest become privatized such as education, public health, housing and public space (Kressel, 1998). Privatization of public space can be in form of buildings such as shopping malls, coffee houses, festival market places, fitness centers, themed historical destination, juice bars, pay-for-playground and the like (Day, 1999).

According to Slangen (2005), one of factors which push privatization of public space is financial issue. When government's budget for this field being cut, public open space quality tends to decrease. This situation solved by privatization, whereby private sector invests a sum of money to enhance the quality and management of public open space.

Problems arise when such public realm entered in 'private region', particularly in issue of 'profit oriented tradition' of private sector. Krupa (1993) claims that privatization has transformed the forums for public life; cities have become "a series of racially and economically segregated private enclaves". Kressel (1998) - in the critics of fast growing of mall as one kind of public space privatization - states that privatization of public space has some immediate commercial purposes. It can be highly profitable to developers, and it enables large-scale property owners to exclude "undesirables" - the homeless, the downmarket, the non-shoppers - from places of investment and privilege intended to attract upscale suburbanites, the urban elite, and tourists with disposable income. Besides that, Kressel worries that public space privatization will destroy democracy. According to Kressel, democracy cannot survive when we have no place to gather where there is "no purchase necessary" (Kressel, 1998). It is similar with

Kohn (2004) who claims that one of the key components of transforming public space into privately-controlled space is that it impacts who can occupy space and what types of activities can be engaged. She argues that the current trend of privatizing public space has sociological implications that it limits free speech, a central underpinning of having a democratic polity. Day (1999) claims that privatization push consumerism and control audience behavior and design.

Positive point of view of privatization relates to management and quality improvement of public open space (Melik, 2009; Slangen, 2005). Melik (2009) states that recent privatization trends should not be seen as a threat but as a new form of public space development and management.

\section{Public Open Space and Quality of Life}

All aspects of the development programs aimed to enhance people quality of life (QOL). 
Research in QOL becomes important to ensure that planning and investment reach the goal effectively (Beck, 2009). 'Quality' refers to level of goodness of any character/condition, but it would be different among people. Schoemaker et al., (1990) defines QOL as 'individual's overall satisfaction with life'. Cutter (1985) defines QOL as "... an individual's happiness or satisfaction with life and environment, including needs and desires, aspirations, lifestyle preference and other tangible and intangible factors which determine overall well being."

QOL can be seen from two indicators, they area (1) objective indicators, by measuring actual condition of built environment, natural environment, and social and economical aspects; (2) subjective indicators, by measuring evaluative statement of what people feel about any living factors (Maclaren, 1996; Grayson dan Young, 1994; Dissart and Deller, 2000). In research about QOL in urban area, QOL dimension relates to environment factors which has been considered in a broader sense, they are physical, social and economical environment (Das, 2008). One important element in urban environment is public open space (Shirvani, 1985). Public open Space can be seen in various forms, but all have important functions, such as conservation, recreations, relationship with nature, mental and social health maintenance (Lynch, 1965/1990). Study conducted by Marans (1988) states that quality of place, such as public open space, is a subjective phenomenon, everyone has different perception.

Many studies give information that public open space relates to $\mathrm{QOL}$ aspects, such as physical and psychological health, social interaction, rate of crimes and economical value of property. Research carried out by Cattel (2008) shows that a wide range of everyday public open spaces were perceived as having a positive influence on both individual well- being and community life. Jackson (2002) claims that greenery elements must be incorporated into relatively high-density neighborhood designs that include public buildings, open space, mixed land use, and pedestrian walkways to increase physical exercise and enhance civic life. The other works show how public open space relates to physical and psychological health (Chiesura, 2004; Harlan et al., 2006; Hansmann et al., 2007; Song et al, 2007), social interaction and cohesion (Kweon et al., 1998 ; Ravenscroft \& Markwell, 2000; Sugihara and Evans, 2000; Tinsley et al., 2002; Cohen, Inagami \& Finch, 2008;), criminality rate (Kuo and Sullivan, 2001) and economical value of property (Lutzenhisher dan Netusil, 2001; Irwin, 2002; Jim and Wendy, 2007)

\subsection{Methodology}

Research started by conducting pilot survey in Merdeka Square to identify trend of usage and activity pattern occurs in the square. Based on this pilot survey Merdeka Square divided into two main observation zone, they are 'Merdeka Walk' as privatized POS and 'Merdeka Square' which managed by city government. Merdeka Square zone divided into twelve segmentation based on function and activities grouping. In every zone field survey 
conducted to collect data of physical condition and design, variety of activities, and people perception through interview.

There are 113 respondents interviewed, they are randomly chosen in every activity zone. Respondents fill a set of questionnaire, guided by interviewer. Questions consist of several sections as follows: (1) respondents' profile; (2) perception about relationship between public open space and several QOL factors; (3) characteristic of activities done in the square (4) level of satisfaction of physical, social and management factors of the square (5) level of satisfaction of QOL factors. The level of satisfaction of public open space is measured in a five-point Likert scale ranging from "1" for very unsatisfied, "2" for unsatisfied, "3" for neutral, "4" for satisfied and "5" for very satisfied. Using the mean values of the scale, " 3 " is considered to be the midpoint. Thus, any value above 3 is considered somewhat satisfied but of higher level. Similarly with any value below 3 , it is considered to unsatisfied but of lower level.

Behavioral mapping and visual survey through photograph and sketch carried out to identify how variety and pattern of activities take place. Each activity presented using symbols and being draw on base-map. Any physical elements relate to activities occur recorded by sketch and photograph. Weather condition also noted when observation taken. Observation carried out in six time groups from morning until midnight in weekend, when peak activities occur.

\subsection{Results and Discussions}

\section{Merdeka Walk and Lapangan Merdeka: The Design}

Merdeka Square is the largest urban-scale public open space in Medan which has important meaning in the history of Medan. Since Dutch colonial era, it has been used for various social activities. In 2004 Merdeka Walk constructed on the West part of 'original' Merdeka Square and operated since 2005 by private sector in Medan. Design by professional architects, floor level of Merdeka Walk $60 \mathrm{~cm}$ higher than the level of Merdeka Square and they were seperated clearly with fence. Merdeka Walk represents design of modern architecture, with light structure, some are tensile structure, which never exist in Medan before. This area dominated by cafes and restaurants, some are open air and brands of international franchise, such as Pizza Hut and McDonald. There is a little portion of public accessible and 'no-purchase necessary' area, namely Center Point, in form of plaza and a little outdoor sittings around it. Some events such as music and other shows and exhibition carried out in this area sometimes, particularly in special anniversary day celebration.

Meanwhile, under management of city government, there are also some enhancement efforts of Merdeka Square Zone, by redesigning the landscape as well as adding support facilities, such as tot lot, physical exercise instruments and jogging track. In fact, according to respondents, the efforts do not create an 'attractive and beauty' feature 
enough compared with Merdeka Walks. Level of satisfaction of respondent to 'attractiveness/ beauty' aspect of Merdeka Walk is 3.21, higher than the Merdeka Square's with 2.96 mean score. This condition confirms what Danisworo (1989) and Car (1992) state that more pleasant public open space could be reach by high quality architecture. But, this aspect is not majority reason of people to visit Merdeka Walk. Only a few respondents state that 'more attractive' (15.2\%) and 'quality of architecture' (4\%) as their reason visit Merdeka Walk. They refer to 'dining facility' $(71.7 \%)$ as majority reason to visit Merdeka Walk.

\section{Respondents Characteristics}

Visitors of Merdeka Square which interviewed are $53.3 \%$ female and $46.7 \%$ male, $73.9 \%$ residents of Medan, $16.5 \%$ temporary residents and, $9.6 \%$ tourists. Most of them are young people with age bracket of 21-30 48.3\%, kids and teenagers of $10-2029.2 \%, 31-40$ $13.3 \%$ and $41-5018.3 \%$. A half of respondents (51.2\%) are high school/university students, and the rest (48.8\%) are working. Almost all of respondents having private vehicle, majority is motor cycle (52\%). There are $17.4 \%$ of respondents having private car and $30.6 \%$ has no private vehicle.

\section{Activities in Merdeka Square and Merdeka Walk}

The sum of people ever visit Merdeka Walk and Merdeka Square is quiet the same $(43.0 \%: 43.8 \%)$. Cafes and restaurants in Merdeka Walk become majority reason why people visit the place. This condition confirms what Carr et al., (1992), Gehl (2002) and Avila (2001) state that such facilities are preferred physical elements of public open space which increasing comfort. Meanwhile, Merdeka square also has 'favorite special activity' related to physical activity, since majority reason why people come to the place is 'sport facilities'. It can be said that, though there is a 'gap' in physical quality between the two public spaces, each place offer different features.

It found that people come to open public space - both in privatized and public area infrequently, but the frequency can be up to 1-4 times a month. Majority people come with friends and family; they stay in public open space 1-3 hours, most of activity done is social interaction with friends and family members.

A public open space is success when it can be a conducive place for social interaction (Danisworo, 1989; Whyte, 1985), attracts many visitors to do their activities there (Danisworo, 1989; Whyte, 1985), with a wide range of activities (Rivlin, 1994; CABE and DETR, 2001), supporting recreation and informal activities (Whyte, 1985; Project for Public Space, 2000). From behavioral mapping conducted, it found that Merdeka Square reach peak hour in Sunday Morning, between 05.00 - 10.59 and Sunday afternoon from 16.00 to 18.59. A wide variety of activities occur, such as sport (football, volley ball, basket, wallclimbing, run, thai-chi and physical exercise, etc), playing, even just sitting, strolling or talking with friends and almost all activities done in groups.

Different with Merdeka Square, Merdeka Walk's peak hour occurs on Saturday and Sunday afternoon, and Saturday and Sunday night. In weekend, activities take place in 
Merdeka Walk go on up to midnight, with major activity is dining, almost done in groups too.

According to Danisworo (1989), from psychological aspect, public open space should create comfort and safety. It could be achieved when public open space controllable by activities occur up to 24 hours with supporting facilities such as shops, restaurants and cafes (Danisworo, 1989; Car, 1992; Rivlin, 1994; Project for Public Space, 2000; Gehl, 2002). In Merdeka Walk activities occur until midnight, when at the same time, almost no activity 'behind' that place, that is in Merdeka Square. From observation, it found that on peak hours of Merdeka Walk at night, jogging track area of the square is functioned as car park. It becomes the middle up class' cars of Merdeka Walk visitors. It can be said that urban life and vitality promoted by Merdeka Walk, but in the same time Merdeka Square behind it being alienated.

Tabel 1: Activity Characteristics Occur in Merdeka Square and Merdeka Walk

\begin{tabular}{|c|c|c|c|}
\hline Activity Charactariatica & Choice & $\begin{array}{l}\text { Mardgid. } \\
\text { Souare } 5\end{array}$ & $\begin{array}{l}\text { Wercasa. } \\
\text { Walk is }\end{array}$ \\
\hline \multirow{2}{*}{ Frequency of vats } & \& 1times & 31.6 & 37.1 \\
\hline & 1.4 trmes & 42.4 & 49.1 \\
\hline $\begin{array}{l}\text { Come to public open } \\
\text { space individualgroups? }\end{array}$ & When frendstamil & 69.6 & 73.9 \\
\hline
\end{tabular}

\begin{tabular}{|c|c|c|c|}
\hline \multirow{4}{*}{ Mapor actity } & $\begin{array}{l}\text { Socal intaraction whi } \\
\text { triends }\end{array}$ & 44.7 & 62.5 \\
\hline & Thteracton wh fanly & 132 & 21.4 \\
\hline & Sport & 289 & \\
\hline & Eeng alone,us: dinng & & 11.0 \\
\hline \multirow{3}{*}{ Transportation mode } & Motor cjoe & 522 & 49.5 \\
\hline & Car & 229 & 279 \\
\hline & Rubic transport & 203 & 18.9 \\
\hline \multirow{3}{*}{ Vots time } & $1600-1839$ & 383 & 25.5 \\
\hline & $6500-1059$ & 23.5 & \\
\hline & $1900-2139$ & & 50.4 \\
\hline
\end{tabular}

Source: Data Analysis, 2011

\section{Perception and Satisfaction Level of Public Open Space}

How to determine the criteria of good quality public open space depends on what people needs which relates to interaction and people perception (Kallus, 2001). Some studies on QOL and its relation to physical elements of urban space carried out by measuring people satisfaction (Campbell, 1976; Marans, 1988; Salleh, 2008). For Merdeka Square case study it found that most people believe that public open space influence their physical health $(90.8 \%)$, psychological comfort $(89.2 \%)$, social interaction quality $(88.3 \%)$ and economical value of property $(85.6 \%)$. Majority people interviewed state that they are 
'satisfied' (47.5\%, score 4) and 'very satisfied' (8.3\% score 5). There are $37.5 \%$ of respondents state 'neutral' (score 3 ) with their whole life. Satisfaction level of some aspects of QOL such as family life, education, income and health, shows that the mean score is higher than 'neutral'. The lowest level of satisfaction found in urban environment aspect which the mean score is 2.84 (see Table 2)

Table 2: Level of Satisfaction of Some Aspects of Life

\begin{tabular}{|c|c|}
\hline Aspects of Life & Level of Satisfaction Mean Score \\
\hline Family Life & 3.89 \\
\hline Politic and Democracy & 3.03 \\
\hline Health & 3.59 \\
\hline Education & 3.60 \\
\hline Employment & 3.36 \\
\hline Income & 3.34 \\
\hline Housing Environment & 3.39 \\
\hline Urban Environment & 2.84 \\
\hline Whole life & 3.57 \\
\hline
\end{tabular}

Source: Data Analysis, 2011

Satisfaction level of public open space - both the privatized (Merdeka Walk) and the public area (Merdeka Square) - shows similar mean score (3.47 and 3.26), so people are generally satisfied. People are not satisfied for two aspects, they are toilet and parking for the two public spaces. The highest satisfaction level found in 'sport area' (in Merdeka Square) with 3.61 mean score, and 'dining area' (in Merdeka Walk) with 3.63 mean score. The contrast mean score found in management aspects, such as cleanliness, attractiveness and orderliness, when Merdeka Square has lower score (mean score lower than 3) and Merdeka Walk's mean score higher than 3 (Table 3). It found that people generally satisfied with management aspects of Merdeka Walk and unsatisfied with such aspects of Merdeka Square. It can be said that privatization has improved public open space management (Slangen, 2005)

No significant difference about accessibility aspect to both public spaces according to people satisfaction (table 3). Through interview it found that almost people who visit Merdeka Square ever went to Merdeka Walk, and those who visit Merdeka Walk ever came to Merdeka Square.

Table 3: Level of Satisfaction of Merdeka Square and Merdeka Walk

\begin{tabular}{|c|c|c|}
\hline \multirow{2}{*}{$\begin{array}{c}\text { Factors of PUBLIC OPEN } \\
\text { SPACE }\end{array}$} & \multicolumn{2}{|c|}{ Level of Satisfaction } \\
\cline { 2 - 3 } & Merdeka Square & Merdeka Walk \\
\hline Distance from home & 3.06 & 2.94 \\
\hline Accessibility & 3.31 & 3.23 \\
\hline Width & 3.62 & 3.24 \\
\hline
\end{tabular}


Nasution, A. D., \& Zahrah, W. / Asian Journal of Environmen-Behaviour Studies, ajE-Bs, 2(5) Oct / Dec 2017 (p.71-83)

\begin{tabular}{|c|c|c|}
\hline Car Park & 3.01 & 2.88 \\
\hline Toilet & 2.42 & 2.55 \\
\hline Playing Area & 3.37 & 3.16 \\
\hline Sitting Area & 3.41 & 3.37 \\
\hline Sport Area & 3.61 & - \\
\hline Praying Area & 2.95 & 2.76 \\
\hline Dining Area & 3.18 & 3.63 \\
\hline Street Vendor /Informal & 3.14 & 2.91 \\
\hline Sector & & 3.50 \\
\hline Trees & 3.42 & 3.27 \\
\hline Garden & 3.34 & 3.26 \\
\hline Safety & 3.10 & 3.26 \\
\hline Cleanliness & 2.75 & 3.21 \\
\hline Beauty/Attractiveness & 2.96 & 3.11 \\
\hline Orderliness & 2.93 & 3.04 \\
\hline Management & 2.94 & 3.33 \\
\hline Recreation Function & 3.26 & 3.46 \\
\hline Social Interaction Function & 3.26 & - \\
\hline Democracy/Politics Activity & 3.10 & 3.23 \\
\hline Function & & 3.17 \\
\hline Ecology Maintenance Function & 3.16 & 2.87 \\
\hline Protection from sun and heat & 2.87 & 3.22 \\
\hline Traffic Comfort & 2.92 & 3.45 \\
\hline Variety of Activity & 3.37 & 3.47 \\
\hline Night Light & 2.93 & \\
\hline Satisfaction of Overall Public & 3.26 & \\
\hline Space & & \\
\hline
\end{tabular}

\subsection{Conclusions}

Design and quality of public open space influence the use of public open space and activities occur in the place (Abu-Ghazzeh, 1996; Golicnik and Thompson, 2009). According to Beck (2009), high quality, well designed and managed parks and urban public spaces will promote quality of life. Since privatization, Merdeka Walk has been standing as a place with good quality design of architecture. From this point of view, the design and management - through privatization - is success in generating public life. It can be said that private sectors are more capable in managing public space since people are unsatisfied for physical quality aspects of Merdeka Square but satisfied for such aspects of Merdeka Walk.

The clear distinction between two areas is the livability at night, when there is no significant activity occurs in Merdeka Square but lot of people stay in Merdeka Walk which 'stands advance' and being 'full of light' while Merdeka Square seems being 'left behind' and 
'darker'. Since quality of lighting at night relates to level of safety and security in public space (Gehl, 2002), further research needed to study safety and security matter at night in Merdeka Square.

Though physically Merdeka Walk is clearly separated with the 'original' Merdeka Square, people are generally satisfied with its accessibility and social interaction function, same as their opinion about such aspects for Merdeka Square. Since majority respondents own private vehicle - which shows their middle up economy class - further research needed to investigate perception of lower income people about public open space in relation with their quality of life, so it can be claimed that open public space is made for all class of people.

However, with its limitation in physical quality and management aspects, Merdeka Square keeps providing its function as urban space where a wide range of public activity occurs. It shows that people really needs public open space to maintain their quality of life though its quality is not good enough.

\section{Acknowledgement}

The authors are grateful to Professor Abdul Ghani Salleh and Dr. Julaihi Wahid for their precious transfer of knowledge. Thanks are due to students of Urban Planning Class, Architecture Department, University of Sumatra Utara and many people for their generous helps in providing all process of this study.

\section{References}

Abu Ghazzeh, Tawfiq M, 1996, Reclaiming public spaces in space: the ecology of neighborhood open the town of Abu-Nuseir, Jordan Landscape and Urban Planning 36 ( 1996) 197-2 16

Beck, H., 2009. Linking the quality of public spaces to quality of life. Journal of Place Management and Development Vol. 2 No. 3, pp. 240-248

CABE and DETR (2001) The Value of Urban Design, London: Thomas Telford

Carr, S, Francis, M.Rivlin, L.g., and Stone,A.M.(1992) PublicSpace,Cambridge: Cambridge University Press

Campbell, A., Converse, P.E., Rodgers, W.L. (1976), The Quality of American, Urban Studies, No.5, pp.737-54

Cattel, V; Dines, N,; Gesler, W; Curtis, S; (2008), Mingling, observing, and lingering: Everyday public spaces andtheir implications for well-being and social relations, Health \& Place 14 (2008) 544-561

Chiesura, A. (2004) The role of urban parks for the sustainable city. Landscape and Urban Planning, 68, 129-138.

Cohen, D. A.; Inagami, S.; \& Finch, B. (2008). The built environment and collective efficacy. Health \& Place, 14,198208. 
Cutter, S.L., (1985). Rating places: a geographer's view on quality of life. Resource Publications in Geography, the Association of American Geographers.

Das, Daisy, (2008), Urban Quality of Life: A Case Study of Guwahati, Springer Science+Business Media B.V., Soc Indic Res (2008) 88:297-310

Danisworo (1989) Konsep Peremajaan Kota, Institut Teknologi Bandung

Day, Kristen (1999) Introducing Gender to the Critique of Privatized Public Space. Journal Of Urban Design, Vol.4, No. 2

Dissart, J.C., Deller, S.C., 2000. Quality of life in the planning literature.Journal of Planning Literature 15 (1), 135161.

Gehl, Jan. (2002) Public Space and Public Life City of Adelaide: 2002. City of Adelaide, Adelaide.

Goli"cnika, Barbara; Thompson, Catharine Ward (2010), Emerging relationships between design and use of urban park spaces, andscape and Urban Planning 94 (2010) 38-53

Grayson, L., Young, K., 1994. Quality of Life in Cities: An Overview and Guide to the Literature. The British Library, London.

Hansmann, R., Hug, S.-M. \& Seeland, K. (2007) Restoration and stress relief through physical activities in forests and parks. Urban Forestry \& Urban Greening, 6, 213-225.

Harlan, S. L., Brazel, A. J., Prashad, L., Stefanov, W. L. \& Larsen, L. (2006). Neighborhood microclimates and vulnerability to heat stress. Social Science \& Medicine, 63, 2847-2863.

Irwin, E., G. (2002). The Effects of Open Space on Residential Property Values. Land Economics.78: 465-480.

Jacobs, Jane, (1961). The Death And Life of Great American Cities, New York: Random House

Jackson, LE, (2003). The relationship of urban design to human health and condition, Landscape and Urban Planning 64 (2003) 191-200

$\mathrm{Jim}$, C.Y. and Chen,W. Y. (2006a). Recreation-amenity use and contingent valuation of urban greenspaces in Guangzhou, China. Landscape and Urban Planning 75: 81-96.

Jim, C.Y. and Chen, W.Y. (2006b). Impacts of urban environmental elements on residential housing prices in Guangzhou (China). Landscape and Urban Planning 78: 422-434.

Jim, C.Y. and Chen, W.Y. (2007). Consumption preferences and environmental externalities: A hedonic analysis of the housing market in Guangzhou. Geoforum 38: 414-431.

Kallus, Rachel (2001). From Abstract to Concrete: Subjective Reading of Urban Space. Journal of Urban Design, Vol. 6, No. 2, 129-150

Kaplan, Stephen; and Kaplan, Rachel, 1982, Humancsape: Environment for People, University of Michigan. Michigan : Ulrich's Book 
Nasution, A. D., \& Zahrah, W. / Asian Journal of Environmen-Behaviour Studies, ajE-Bs, 2(5) Oct / Dec 2017 (p.71-83)

Kohn, M., (2004). Brave New Nighborhood :The Privatization of Public Space, New York: Routledge

Kressel, Shirley (1998). Privatizing the public realm, New Democracy Newsletter, July-August 1998

Kruppa, Frederique (1993). The privatization of public space, MA, thesis, www. translucency.com/frede/pps.htm, accessed 26 February 2011.

Kuo, F. E.; \& Sullivan, W. C. (2001). Aggression and violence in the inner city: effects of environment via mental fatigue. Environment and Behavior, 33(4),

Kweon, B.-S., Sullivan, W.C. and Wiley, A.R. (1998). Green common spaces and the social interaction of inner-city older adults. Environment and Behavior 30(6): 832-858.

Lever, J. P. (2000). The development of an instrument to measure quality of life in Mexico City. Social Indicators Research, 50, 187-08.

Lutzenhisher, M. and Netusil N., A. (2001). The Effect of Open Spaces on a Home's Sale Price. Contemporary Economic Policy 19: 291-298.

Lynch, Kevin (1960). Image of The City, MIT, Massachusets.

Lynch, Kevin (1965/1990). The Openness of Open Space. In : Banerjee, T., Southworth, M. (Eds), City Sense and City Design : Writings and Projects of Kevin Lynch, The MIT Press, Cambridge, pp 396-412.

Maclaren, V.W., (1996). Developing Indicators of Urban Sustainability: A Focus on the Canadian Experience (Report prepared for State of the Environment Directorate, Environment Canada, Canadian Mortgage and Housing Corporation, IntergovernmentalCommitteeonUrbanandRegionalResearch). ICURR Press, Toronto.

Madanipour, A. (1999). Why Are the Design and Development of Public Spaces Significant for Cities, Environment and Planning B; Planning and Design, 26 (6), 879-891.

Marans, RW, (2003). Understanding environmental quality through quality of life studies: the 2001 DAS and its use of subjective and objective indicators, Landscape and Urban Planning 65 (2003) 73-83.

Melik, RV; Aalst, IV, Weesep, JV (2009). The private sector and public space in Dutch city centres, Cities, 26 (2009) 202-209.

Project for Public Spaces (2000). How to Turn a Place Around: A Handbook of Creating Successful Public Spaces, New York: Project For Public Space

Ravenscroft,N.; \&Markwell,S. (2000). Ethnicityand theintegrationandexclusion of young people through urban park and recreation provision. Managing Leisure, 5, 135-150.

Rivlin, L.G. (1994). Public spaces and public life in urban areas. In Neary, S.J., Symes, M.S., Brown, F.E. (Eds.). The Urban Experience: A People-Environment Perspective, pp. 289-296. London: Taylor \& Francis Group.

Rossi , Aldo (1982). The Architecture of the City , Cambridge: MIT Press.

Salleh, Abdul Ghani (2008). Neighbourhood factors in private low-cost housing in Malaysia, Habitat International 32 (2008) 485-493. 
Schoemaker, S.A., R.T. Anderson and Czajkowski (1990). Psychological test and scales, in B. Spiller (ed.), Quality of Life Assessment in Clinical Trials, Roven Press, New York.

Shirvani, Hamid (1985). The Urban Design Process, Van Nostrand Reinhold Company, New York.

Slangen, Ron H. (2005). The Role of Public-Private Partnership in Urban Park Management: An Evaluation of Bryant Park,New York City. Thesis. Faculty of Architecture and Planning Columbia University.

Song, Y., Gee, G. C., Fan, Y. \& Takeuchi, D. T. (2007). Do physical neighborhood characteristics matter in predicting traffic stress and health outcomes? Transportation Research Part F: Trafßc Psychology and Behaviour, 10, 164176.

Sugihara, S.; \& Evans, G. W. (2000). Place attachment and social support at continuining care retirement communities. Environment and Behavior, 32(3), 400-409.

Tinsley, H.E. A., Tinsley, D. J.\& Croskeys, C.E.(2002).Parkusage, social milieu, and psychosocial benefits of park use reported by older urban park users from four ethnic groups. Leisure Sciences, 24, 199-218.

Whyte, William H. (1985). The Social Life of Small Urban Space. Washington DC: The Conservation Foundation. 